\title{
Can 'Control-Order' be Implanted into the Counter-Terrorism Policy of Bangladesh? A Critical Assessment
}

\author{
Mohammed Shahjalal ${ }^{1 \& 2} *$ \\ ${ }^{1}$ Department of Law, East West University, Bangladesh; and ${ }^{2} \mathrm{PhD}$ Fellow, Glasgow Caledonian University, UK. \\ *Correspondence: shahjalal@ewubd.edu (Mohammed Shahjalal, Senior Lecturer, Department of Law, East West University, \\ Bangladesh)
}

\begin{abstract}
This research will be specifically focusing on implemented legislations for eliminating terrorism. There is no need to mention exclusively again that it began many years ago. It ignited mostly after the post 9/11 era. The Bush \& Blair management then immediately applied many different and notorious counter-terrorism tactics. Among all; the infamous "Control Order" was authorized by most of the regimes like Guatemala to Tihar Jail, India. Arguably except Bangladesh, this brutal method of torture was applied in almost every counter-terrorism cell. Needless to say it started mostly after the 'Twin Tower' destruction. The Allied Forces (Mainly UK and USA) had literally chosen to instigate 'Control-Order' on almost every Muslim individual and almost every counter-terrorism agencies started to implement 'control-order' within regular basis.
\end{abstract}

Keywords: Terrorism, Human rights international counter terrorism provision, Control order, and Islam phobia.

\section{INTRODUCTION}

This research will emphasize on whether this 'controlorder' can be labeled as 'effective measures' for countering terrorism. The burning question should be whether the above mentioned method was against preventing terrorism actually operational or it was a massive breach of core Human Rights. Many scholars even asked that, is the 'control order' just confirming Barbarianism or prevention? It seems by opting out some of the core human rights are getting mallet by penalizing such individuals who had nothing to do with terrorist activities. Furthermore it must be scrutinized that, whether major legislations on terrorism like 'prevention of terrorism act 2005', 'counter-terrorism acts 2008' and many more relevant provisions worldwide are legally compatible with the Universal Declaration of Human Rights (UDHR),
European Convention on Human Rights (ECHR), The International Covenant on Civil and Political Rights (ICCPR) and finally with Anti Terrorism Act 2009 of Bangladesh or not.

\section{Control order}

A preamble of control order is essential to understand the prevention of terrorism. It is not worthy that; numerous provisions were already available to prevent terrorism since the cold war era. But after the 9/11, tension escalated radically. Some provisions were enacted immediately to prevent radical islamification worldwide. This last part was crucial because the UK Intelligence had predicted on the possibility of creation on a 'crusade land' or more probably the creation of 'Islamic-caliphate'. 'Consequently', the Blair administration decided to wipe out all necessary legal proceedings and implement 'control order' as 
soon as possible. As mentioned above countless people (mostly Muslims) were being abducted and sent to become detention centre or safe houses. It was later testified by an accused in court that, they were inhumanly tortured and repeatedly reminded that 'human rights are for human beings not for terrorist like you'. Needless to say, these approaches simply triggered many of the prisoners united to form up insurgency organizations worldwide like ISIS, ISIL, Boko-Haram and Lashker-e-tayeba. This is quite normal, when fundamental rights are wiped out; anarchism becomes very successful. For example, the rise of anarchy in $17^{\text {th }}-18^{\text {th }}$ century.

A control order is an order made by the Home Secretary of the United Kingdom to restrict and detain an individual's personal freedom. The basic objective would be for the purpose of protecting members of the public from a risk of imminent event of terrorism. These measures are empowered from the infamous Prevention of Terrorism Act 2005. Control order can be defined into two categories.

1) The first type is sanctioned for at least a year and will be comprised of strict and incompatible conditions with basic human rights provisions, such as a complete lockdown to a home and this act is nonderogating.

2) The later form is to simply opting-out of some the basic human rights by restricting the movements of an individual in a public emergency situation with a strict surveillance and it is derogating. The Prevention of Terrorism Act 2005 makes appeal rights extremely limited and the absence of double jeopardy restrictions. Hence, this has led to many judgments which were considered highly controversial. This is because; the list of restrictions in a control order may really long. It can be compared with a closed circuit camera (CC Camera) where an individual's liberty is restricted on what the person can use or possess his place of residence, place of work, and where he can travel.

Furthermore, the suspected person's passport can be confiscated immediately. The police may visit his home at any time, armed or unarmed. They will not be bind to report to any higher authorization. Furthermore, the suspect must allow the police to electronically tag him so every movement of his can be tracked. In a nutshell, control order confirms a prison within a prison; which flawlessly undermines the spirit of basic human rights. For example, rather than restricting liberty, it completely wipes out liberty. Therefore, it is called a derogating control order because it infringes Article 5 of the ECHR. ${ }^{1}$ This can only happen if there is derogation and if the Home Secretary applies to a court for the authority. ${ }^{2}$ Hence derogation is only be allowed when there is a "war or other public emergency threatening the life of the nation". It must be noted that, these insurgents are not subject to Geneva Convention, protocol 4. Also, the ECHR precisely states that the government must not deprive any person's liberty without due process of law. ${ }^{3}$

\section{Has the law developed?}

The then House of Lords (now the Supreme Court of $\mathrm{UK}$ ) issued a filament of significant judgments on the future of the control order. It was enshrined that, someone cannot be forced to stay in their own home more than 16 hours. In a decided case, control order was denounced as a punishment without a fair trial. Consequently, new rules were set out for the use of intelligence material after a judgment on secret evidence which had 'direct effect' from the ECJ.

The judges condemned control order by saying that that it had always been denied a fair trial. In fact, a Judge remarked that, these notorious elements were only created to disregard the ECHR. It never meant to enact fair trial. Those allegations seem to be true because the suspects did not even know the gist of the case against them. The Lords ruled tout hat, it is anyone's right to know an "irreducible minimum" of the allegations. However, there will be no shortage of examples for prospecting the weaker nature of this types of provision and it is obviously quite clear that this 'control order' propaganda from PTA 2005 is full with fundamental errors otherwise it could not be disrespected by the honorable judges. Therefore, it may be wise enough to say that the law has not developed but has started slight progress since 2007 . 


\section{Post 9/11}

As the prologue is already discussed above, following the UK parliament, most of the member states of The North Atlantic Treaty Organization (NATO) started to implements control order which was enacted on the first week of March 2005. However, these actions caused lots of political controversy; as some of the MPs from all over the world were never ready to accept this monstrous torture method. In fact they argued back that this method must not dismantle immediately. But, majority of the politicians particularly the members of the House of Commons, UK supported for 'control order' unreservedly. Moreover, the pro members even started to call the protestors as 'traitors'. Consequently after a hours and hours of heated debate, which is also categorized by the media $(\mathrm{BBC})$ as the 'parliamentary ping pong' and finally this monstrous element of torture came into light and embedded as a legal elements in many countries anti-terrorism provisions.

However, it is paramount important to understand that, control order falls neither into a civil or criminal aspect. Some experts labeled it as 'no man's land.' For example, the fifteen detainees who were taken from Heathrow Airport and taken into custody by power lay down by the Anti-terrorism, Crime and Security Act 2001. They were inhumanly tortured and kept as prisoner for months in HM Prison, Belmarsh with full application of control orders. The Military Intelligence 5 (Mi5) even refused to put forward their case to Crown Prosecution Service (CPS). However, eventually they were sent to Royal Court of Justice in London and acquainted immediately as they were found not guilty. On March 24 2005, one of the accused named as Abu Rideh Karim, allowed himself a newspaper interview, where he denied having any connection with terrorism. Furthermore, he claimed that, he was a member f Iraqi Republican Guard and he risked everything to dodge Saddam regime to leak confidential information to Military Intelligence 6 (Mi6). But still control order was imposed on him because he flew from Baghdad, Iraq.

During his stay in Belmarsh, he was informed that, three procedures will be followed.

1) $\mathrm{He}$ is totally not allowed to make any arrangements to meet with anybody not even a lawyer or CPS, but he can meet them if he signs in a forceful confession. (He was engaged with terrorist activities and he was treated reasonably well here).

2) Even if he agrees, he cannot attend any prearranged meetings or gatherings, but may be present at the anti-war demonstration at Hyde Park last Saturday with high surveillance.

3) $\mathrm{He}$ is banned from having visitors to his own home (not even his parents, wife or his infant daughter) unless they are vetted in advance from the Home Office, UK; which is fairly a longer process.

4) $\mathrm{He}$ is allowed to arrange to attend group prayers at a mosque inside the detention centre with fellow prisoners but that was also be finished within 15 minutes.

Astonishingly, on mid 2005 that, it was also found out by the court that all the individuals names were confused with some other suspects because of clerical error (wrong identification).

\section{Significance of anti-te rrorism legis lation}

It is very important to recognize that, anti and counterterrorism is not being mixed up. Even the renowned scholars sometimes confuse them as the equivalent. In fact, they are quite different in every aspect of jurisprudence. For example, a legislation which is designed all types of laws passed in the purported aim of fighting terrorism is indeed Anti-terrorism and they usually but not always, strictly follow explicit terrorist events. Moreover, an Anti-terrorism legislation is generally comprised with a specific amendment which would be allowing the regime to circumvent its own or adopted international legislation; when combating terrorist activities. But it must be performed under the grounds of military necessity. Hence, total suspension of constitutional procedures would amount to the form of lois scélérates or a law to punish the devil. It may very unfairly stifle all kinds of accepted remonstrations. Also, critics often assert that an anti-terrorism legislation may even jeopardize the whole democratic process by igniting a violent mutiny. Five years ago Hugo Chávez remarked in an UN general assembly that, this 'control order' will only create more lucifer 
rather than angels. Which we can see these days for the case of ISIS or similar.

These days most of the Governments often seem to agree that, insurgency should only be dealt with military aggression. This may not be the case of success at all perception. Yes, terrorist organizations are not necessarily a subject of 'peaceful negotiation' and compromising with them may result vindictive as well. But one must remember unleashing these measures are only temporary measures, not to be a permanent solution. The tactics applied by Turkey may be a viable option. The Erdoğan administration made a pact with the peshmergas to combat with the ISIS. The peshmergas were always considered as an enemy of the state of turkey. But to create a diversion to defeat the ISIS, Turkish Army heavily armed them. Some scholars even compared them with the Congressman Charlie Wilson who convinced the White house to hand over anti air-craft missile system to the Taliban to defeat the mighty 'Red Army'. However, Mr Erdoğan and Charlie Wilson had to pass such a law which would never had a monstrous counter-terrorism elements like control order.

However, still in these days anti-terrorism legislations seem to include preventive detention (a detention without trial with an indefinite period of time). The UK, USA and Australia seem to have issued fewer warrants. It does not matter how heinous the crimes are, a fair trial cannot be conducted by such a short cut way. It is noteworthy that even Nazis and Nippon officers had fairer trial or at least lesser detention; which control order seem to have nullified. The hypothetical or text book Counter-terrorism method should be the practices, strategy, modus operandi, and planning that government, police departments, militaries, intelligence agencies and judiciaries espouse in response to credible terrorist threats.

Moreover, the tactics of terrorism should be well adopted by the governments. Not all insurgents use terror as a tactic, and some choose not to use it because other tactics might work better for them. Apart from modern day ISIS example, the Oklahoma City bombing may be a prominent example. And it raises further question; if the terrorism is part of a broader insurgency, counter-terrorism may also form a UniversePG I www.universepg.com part of a similar analogy, but it should be well remembered that the suppression of political, economic, and other measures may encourage more insurgency than the specific acts of terror. For example, the recent terror event happened in Christchurch, New Zealand. The concerned counter terrorism unit for New Zealand was criticized for not exercising Foreign Internal Defence (FID), which is a term used by almost every country for suppressing insurgency, or reducing the possibilities under which insurgency could develop. It is noteworthy that, counter-terrorism includes both the detection of potential acts and the response to related events.

\section{Recent controversy}

After implementing this 'control order', according to the most up to date figures for January 2010, was forty five since the system was created, but after a decade, it almost crossed more than ten thousand. Many of the foreigners were being detained and later deported. This method managed to set up a new template of restrictions which are listed below-

1. Electronic tagging

2. No passport in possession.

3. No living at one traceable address

4. Home Curfews

5. Restrictions on relatives and visitors

6. No internet

7. Attending only one assigned mosque (subject to discretionary report by Mi5)

8. Daily reporting to the armed police

9. Daily monitoring and tapping of phone conversation

10. Removal of the prohibition on post-charge questioning.

11. Absolutely no legal assistance; not even allowed to meet the CPS for 'plea bargning'.

12. If needed much longer detentions to be imposed without any justification.

Moreover, a register and monitoring was assigned for those convicted of terrorism related offences like they are similar to the Violent and Sex Offenders. The use of "intercept evidence" was removed. And the register was empowered to seize the assets of suspects. The Police will be able to remove documents from a 
property search to decide whether or not they need to be legally seized as part of an investigation without any reasonable doubt. Greater use of DNA samples, and powers to allow the police to take fingerprints or DNA from those subject to a control order (these orders are civil restraints, not criminal offences). It is noteworthy that, the Police and Criminal Evidence Act (PACE) 1984 and Serious Organized Crime and Police Act (2005) precisely forbid any police man to perform such actions. In 2019 when the ban on taking photograph of certain class of security forces came into force; it created a massive controversy. It is an offence to elicit, attempt to elicit, or publish information of a kind likely to be useful to a person committing or preparing an act of terrorism. Like a member of Her Majesty's Armed Forces, a constable, the Security Service (both Mi5 and 6), the Secret Intelligence Service (the Elite guard who protects the Prime Minister of the UK), or member of the Government Communications Head-Quarters (GCHQ). Any person found guilty faces minimum of 10 years imprisonment with an unlimited fine. However, a defense is available for the accused (the police) with this offence to prove that, they had a reasonable doubt for their action. So the onus is totally opposite here. ${ }^{4}$

The Parliamentary debate on this notorious elements were very limited owing to the fact that in earlier versions of the Bill the offence of exposing confidential information, which may be extremely useful to an individual preparing or committing an act of terrorism. This was also the case throughout the debate in the Standing Committee. But some demand made by the opposition, to change the phrase; the minister interfered by addressing current case law ( R v $\mathrm{K}$ ) and also said there is no necessity for that because that would only restated earlier laws. The law against eliciting or publishing information "likely to be useful to a person committing or preparing an act of terrorism" was extended to encompass police constables in a raft of unscrutinized amendments. ${ }^{5}$

\section{Why the future smells more damaging?}

On the direct command of the security officials, all the confidential information was prepared to input in to the public database and MI5 almost had all the personal information of the suspects. It included all telephonic conversations, transcripts of audio bugs, taps, and tip-offs. Furthermore, this info's were shared among other intelligence agencies around the world. In fact, because of these classified information intelligence agencies forcefully embedded the suspects to take part in risky covert operation. After the forceful confession, intelligence officers then make an assessment about what the information means - and this helps them to target the people they think are the most dangerous. So, needless to say the above lines of actions are standing on the vicinity of abuse of basic human rights and all these provisions are supreme candidates of incompatibility with the principles of ECHR with a high claim.

Furthermore, question arises, would it be interesting to make a comparison with the incident happened in Western Algeria, Bosnia, Kosovo and France. They are considered as one of the most brutal occupations of the history, where all sorts of possible injustice happened with the rebels or insurgents (a similar concept of application of control-order in Guatemala), which also created a lot miscreants like today's ISIS or ISIL. The present provision relating control-order is also criminalizing the similar way to the suspects in London, Paris, Berlin, Riyadh, Tel-Aviv, New York, Karachi and Mumbai. In almost the same way to the only difference is the passing of time. It has already black-marked a damaging reputation to the UK who has more than 3000 years old 'Rule of Law' legacy.

Already this measure received numerous hatred and bad faith all over the world with also a question for proper democracy in UK. There is definite justification to fight and eliminate against terror but with proper preparation not just following blindly USA, Israel and Australia. If a glance could be made on one of the control suspects feeling about it might get clearer $\mathrm{AE}$ (it is not permitted to use the real name) said on an interview in BBC "Where's the evidence?" He said, it's all classified material, I can't defend myself, I'm in the dark, and living in this nightmare with a shameful identity of a 'terrorist'. Another example is for AE (fictitious name) an IraqiKurdish Imam in his mid forties, who is one of 17 current controlees, and part of the trio who argued that 
they were simply not allowed to $t$ defend themselves in court (barred to meet the CPS), because they have never seen the evidence that led to their forever loss of their personal and religious liberty. His story began in 2002. AE fled from Iraq after being imprisoned at Abu Ghraib jail by Saddam Husain's regime, for becoming a double agent to MI6 and the CIA. He testified that, he spent 80 days with unthinkable torture (controlorder was applied) and remained in "a hole in the ground" with some 150 other prisoners (An unknown UK safe house; possible near to Baskerville). The court dismissed his case with special note that the control order is incompatible with ECHR. Later on, He was given the right to stay indefinably in the UK. Now, the question arises a High value suspect was tortured, and then with no time, he was allowed to settle into a new life as a British Citizen, does it not raise a question that this control order meant to insult the judicial integrity of the UK. And like him, many other's cases were also dismissed.

\section{Control-order is enough to defeat Al-Qaeda, ISIS and other Terrorist organizations?}

This research will now will discuss very briefly about something which is probably remote from my research. But I still feel the urge to discuss. The "war on terror" directed by 'Bush administration' and coownership by Mr Blair and Lord Gold Smith was for eliminating "terror" precisely. For elaboration, to opting out mainstream terrorist organizations. That was the "external" action against terror and implementing these anti and counters terrorism provisions can classified as "internal" actions. Personally it was a bold move but my straight question is how much successful they are now? Is executing Saddam Hussein enough to free the world from weapons against mass destruction? The answer has to be negative.

So, this research is now focusing on the internal action taken, which does not intent to create a debate over whether the invasion of Iraq, Syria, Libya and Yemen was lawful or not, but the question raises again that; is implanting control order be a reasonable step to enforce torture and injustice? For example the case of AE who had gone to his normal life; but would it not be possible that he returned for his retaliation and join with those ISIS? Hence he was innocent not a criminal but many of his co-prisoners decided not to do so just because of control order. Therefore, what all these provisions and precisely 'control order' done is; they all failed at the first place and successfully created more hatred and danger; i.e. expansion of Islamic extremism so that Islamophiba could be taken place. And that exactly what these provisions were not made for.

\section{Blending Control-Order in Anti-Terrorism Act 2009 (B angladesh)}

Now comes the most important part, in 2019 Global Terrorism Index says that Bangladesh is the most successful South Asian country to combat countering terrorism. When the Prime Minister Sheikh Hasina got reelected in 2009, she could have easily ratified control order into the Anti-Terrorism Act 2009 (Bangladesh). The observation made by the international jurisprudence necessitates a significant observation of the legislative endeavors made by Bangladeshi regime to prevent terrorism. The AntiTerrorism Act was passed in 2009 with an amendment of 2012 and 2013. Capital punishment was included, but, implanting control order was always rejected or neglected by the concerned authority.

However, this are not that rosy as they sound, The 2013 amendment specifically empowered the authority to conduct 24 hours surveillance through Zoom, Google Duo, Facebook, Skype, Twitter and Viber or any other internet gadget used by the terrorist person or entity or pose picture or video involving their intended terrorist plot. The Holy Artisan or Kallayanpur incident might be a prudent example, where they posted their threatening gesture to the YouTube and intended to be found by the police to spread terror.

However, the Act is restricted to fix a time limit for concluding of any finding investigation by stating that any concerned law enforcement agency 'must complete the investigation of any case within sixty days of the date on which information is received or recorded under the watch of Code of Criminal Procedure $1898 .^{6}$ 
It is noteworthy that, the Act also defines terrorist activities. ${ }^{7}$ Where it states that, Among others, it says that if any person, entity or foreigner for the purposes of threatening the unity, integration, public security or sovereignty of Bangladesh by creating panic among the public or a section of the public with a view to compelling the Government or any entity or any person to do any act or preventing them from doing any act kills, causes grievous hurt, confines or kidnaps any person or attempts to do so, then the person, entity or foreigner shall commit the offence of 'terrorist activities'. This is far too ambiguous and confusing among other international counter terrorism provisions. This is because; these given interpretations are already available in CrPC 1898. The section further says that if any person, entity or foreigner, for the foregoing purposes, damages or attempts to damage any property of any person, entity or the State; abets or instigates any person to murder, injure seriously, confine or kidnap any person; or abets or instigates to damage any property of any person or entity or the State; or uses or keeps in possession any explosive substance, inflammable substance and arms for the purposes mentioned, then the person, entity or foreigner shall commit the offence of 'terrorist activities'. Unfortunately, these are also the standard definition of abduction, gross bodily harm, arms dealing and homicide set in CrPC 1898; the only difference is along with a Bangladeshi national; a foreigner is included as well. The question remains this law failed to intent to narrow down 'extradition' treaty.

Furthermore, The Act fails to explain the recruitment of outlaws and confirming special surveillance on travel in association with terrorism; however an assortment of mechanisms fits within the limitation of the broader language of the Act in order for not only in but all over the world. It is paramount important that Bangladesh must ratify the UN Security Council Resolution 2178. To deal with the Foreign Terrorist Fighters this local act is not enough but to embed Resolution 2178 is crucial. The benefit would be if the anti-terrorism act 2009 seems handicapped then it is feasible that the Bangladeshi Government can press other charges under Resolution 2178 against the Foreign Terrorist Fighters.

UniversePG I www.universepg.com
It is crucial to understand that, Bangladesh is a member of the Asia Pacific Group on Money Laundering. The Bangladesh Bank, created a Bangladesh Financial Intelligence Unit (BFIU), which will lead the State's efforts in order to comply with the international anti-money laundering or countering the Financing of Terrorism (AML/CFT) standards and international legal sanctions regimes. In the year 2013, Bangladesh Government also enacted the Rules to combat terrorism, namely the Anti-Terrorism Act $2013 .^{8}$

The Act prohibits membership in or support of internationally listed terrorist entities (under the UN Security Council ISIL or ISIS and al-Qaida sanctions regime). The Act also claims to provide for a wide and comprehensive framework providing for mutual legal cooperation among other nations on matters involved in terrorist activities. Under the virtue of this act the Government may constitute one or more Antiterrorism Special Tribunals for speedy and effective trial of the offences committed under the Act. ${ }^{9}$ however, this may be questionable, as in the western jurisdiction terrorism trials are conducted in normal criminal courts; for example Royal Court of Justice in London UK.

Fourth chapter of the Act is devoted towards the enlistment, proscription, and implementation of the United Nations Security Council Resolutions with regard to terrorism. Even though Bangladesh has very fewer experiences compare to other SAARC countries and other parts of the world. Therefore, why emphasizing terrorism with confirming unnecessary diligence. These problems are always dealt by the local police and RAB with almost $100 \%$ success.

Again why portraying a 'poster child' in the region in setting major examples for combating and countering terrorism with a multidimensional approach featuring legislation, law enforcement and the Central Bank, certain human rights organizations opine that the broad definition of terrorism as it appears in the Act of 2009. Once again these mechanisms are imported from the West mainly and it seems they failed subsequently. Then why following their jurisprudence which is full of Human Rights nullification. Embedding control order will only make the law prone to 
'abuses and repression against political opponents, journalists and certain other dissenting voices', and most importantly creation of Bangladeshi Version of 'ISIS'.

\section{CONCLUSION}

Last but not least, my personal view is; control order is a complete failure and far away from its intended objective. This was only created to divide Muslims and non-Muslims and spreading hatred with political agenda. To defeat Bin Laden or Al-Baghdadi's legacy in this country; Islamophiba needs be treat as same with the Islamic extremism. More concise, flexible with wider ranged legislation required to be passed in the parliament. Or otherwise it can be guaranteed that there will be more terror and none one of them will be prosecuted. Al-Baghdadi and B $\mathrm{H}$ Tarrant will get more volunteers from all over world and terrorism will never be defeated.

\section{ACKNOWLEDGEMENT}

Author wishes to thanks who participated in this study by sharing their knowledge and time to make this research successful.

\section{CONFLICTS OF INTEREST}

The author declares there are conflicts of the interest with respect to the research, and publication of this article.

\section{ENDNOTES}

\footnotetext{
${ }^{1}$ Article 5 of the ECHR

${ }^{2}$ Article 15 of the ECHR

3 This process must include informing the person of the accusation against him, giving him access to legal assistance to prepare his defense, and giving him the right to have his case heard and decided in public before a competent court.
}

${ }^{4}$ Although there are exemptions for communications service providers, web caches and web hosting services. There was a mass protest outside Scotland Yard in February 2019. The Home Secretary reaffirmed that the police have a legal right to restrict photography in public places, and stated "the law applies to photographers as it does to anybody else in a public place". The act however does not lay out restrictions for the photography of Community Support Officers as they do not hold the office of Constable.

${ }^{5}$ That passed into the Bill at the end of the debate when the Parliamentary timetable (which had been voted on earlier in the day) expired. When this clause was scrutinized in the House of Lords, and in all subsequent debates, no reference was made to the extension of the law to include police constables.

${ }^{6}$ Section 154 of the Code of Criminal Procedure, 1898.

${ }^{7}$ Section 6 of the Anti-Terrorism Act 2009.

${ }^{8}$ The Rules lay down the procedure of freezing of accounts, funds and assets of individuals and groups in connection with terrorism. The Rules also have a provision (rule no.

${ }^{9}$ Section 28 of the Anti-Terrorism Act 2009.

Citation: Shahjalal M. (2020). Can 'control-order' be implanted into the counter-terrorism policy of Bangladesh? A critical assessment, Asian J. Soc. Sci. Leg. Stud., 2(3), 63-70. https://doi.org/10.34104/ajssls.020.063070 @) क 